\title{
Lactase non-persistent genotype influences milk consumption and gastrointestinal symptoms in Northern Russians
}

\author{
Yulia Khabarova ${ }^{1 *}$, Suvi Tornianen ${ }^{2}$, Sari Tuomisto ${ }^{3}$, Irma Järvelä${ }^{2}$ Pekka Karhunen ${ }^{3}$, Mauri Isokoski ${ }^{4}$ and \\ Kari Mattila ${ }^{5}$
}

\begin{abstract}
Background: Milk is an important source of nutrients. The consumption of milk, however, may cause abdominal complaints in lactose intolerant individuals. The frequency of -13910C/C genotype is known to be high among Northern Russians, exceeding the prevalence in northern Europe. In our study we tested two hypotheses: 1) subjects with lactase non-persistent genotype (-13910C/C) have more gastrointestinal (Gl) symptoms associated with milk 2) subjects with lactase non-persistence avoid using milk.
\end{abstract}

Methods: In total, 518 students aged 17 to 26 years were randomly selected from different departments in the Northern State Medical University (NSMU) for genotyping the lactase activity-defining -13910C/T variant. All subjects filled in a questionnaire covering their personal data, self-reported Gl symptoms and milk consumption habits.

Results: Northern Russians consume very small amounts of milk daily. Among carriers of the lactase non-persistent (LNP) genotype there were 10 percentage units of milk-consumers fewer than among lactase-persistent (LP) subjects $(p=0.03)$. Complaints of $\mathrm{Gl}$ disorders caused by milk were different between the genotypes $(p=0.02)$. Among all types of food analyzed only milk was associated with increased Gl symptoms among subjects with the LNP genotype (OR $=1.95, \mathrm{Cl} 1.03-3.69)$

Conclusions: Subjects with $-13910 \mathrm{C} / \mathrm{C}$ have more Gl symptoms from milk. Subjects with lactase non-persistent genotype avoid using milk. In the case of increasing milk consumption symptoms may increase the need for medical consultation. It is thus important either for people themselves or for health care staff to be aware of lactase persistence/non-persistence.

\section{Background}

Milk is an important source of everyday nutrition. Bovine milk is a rich resource of nutrients containing lipids, proteins, amino acids, vitamins and minerals. Such substances as immunoglobulins, hormones, growth factors, cytokines, nucleotides, peptides, polyamines, enzymes and other bioactive peptides are also present in milk [1,2]. Milk has been considered a major source of calcium as well as the simplest and most "cost-effective" way to ingest calcium $[3,4]$. In that dairy products also

\footnotetext{
* Correspondence: yuliakaterina@rambler.ru

'Department of Family Medicine, Northern State Medical University, Arkhangelsk 163000, Russia and Medical School, Tampere University 33014, Finland

Full list of author information is available at the end of the article
}

provide other important nutrients, their consumption improves the nutritional quality of the diet appreciably $[4,5]$.

This notwithstanding, the consumption of milk has decreased over the last decade in Northern Europe [1,5]. Data on milk consumption in Russia in recent years have been very limited and available only from market analyses, which show a decrease in milk consumption in some regions of country [6]. Consumption is low among young Northern Russians [7]. The above-mentioned properties of milk make it important for everyday nutrition, especially for children. Recently a national program, "School milk", aimed to supply schoolchildren

\section{() Biomed Central}

(c) 2011 Khabarova et al; licensee BioMed Central Ltd. This is an Open Access article distributed under the terms of the Creative Commons Attribution License (http://creativecommons.org/licenses/by/2.0), which permits unrestricted use, distribution, and reproduction in any medium, provided the original work is properly cited. 
with the essential amount of milk daily, has been implemented in Russia [8].

Adult-type hypolactasia, characterized by the downregulation of lactase enzyme activity in the intestine during human growth, is inherited as an autosomal recessive trait $[9,10]$. The first genetic variant associated with adult-type hypolactasia, a one-base polymorphism $\mathrm{C}>\mathrm{T}-13910$ ( $\mathrm{rs} 4988234$ ) upstream of the lactase encoding gene on chromosome 2, was identified in 2002 [11]. This $-13910 \mathrm{C} / \mathrm{T}$ is the most common variant of lactase persistence among Caucasians [12]. Several other population-specific variants nearby have been identified, some of them only suggestive [13-16]. The $-13910 \mathrm{C} / \mathrm{T}$ has been shown to be located in the OCT-1 binding site and acts as an enhancer. Nowadays the genotyping can be used as the test for adult-type hypolactasia with $100 \%$ specificity in cases of unspecific abdominal complaints $[17,18]$.

Milk contains disaccharide lactose, which may cause gastrointestinal problems in adults by reason of its poor digestion in part of population. In Northern Europe lactase persistence is common, which allows the majority of the population to drink milk without any consequences [19]. However, in populations where the frequency of the lactase persistent genotype is rather low the consumption of milk may cause complaints in the digestive tract [20]. The development of symptoms depends on the amount of milk consumed as well as on individual sensitivity. It has been shown that subjects with hypolactasia can tolerate moderate quantities of milk, up to $12 \mathrm{~g}$ of lactose $/ 200 \mathrm{ml}$ of milk. If the daily dose of lactose is consumed in small portions and also with a meal, the likelihood of symptoms is low [20-22].

The most common gastrointestinal (GI) symptoms which characterize intolerance to lactose are flatulence, diarrhea, gurgling, abdominal distension and abdominal cramping [22-24]. The appearance of symptoms is clearly explained by mechanism of lactose utilization. Lactase-phlorizin hydrolase splits the entering lactose into two monosaccharides, glucose and galactose. The lack of lactase activity leads to intake of indigested lactose into the bowel. The osmotic effect causes diarrhea [25], while an increased level of fermentation in the intestine leads to increasing production of gases and thus to flatulence $[26,27]$.

The prevalence of adult-type hypolactasia (lactase nonpersistence, $-13910 \mathrm{C} / \mathrm{C}$ ) among Northern Russians has been found to be $35 \%$ [7]. It has also been shown that the prevalence of the $-13910 \mathrm{C} / \mathrm{C}$ genotype among Russians living in the central part of the country ranges from 36 to $50 \%[28,29]$. This frequency is twice as high as in Finland and many times higher compared with other Scandinavian countries [30-33]. It also exceeds the prevalence of the $-13910 \mathrm{C} / \mathrm{C}$ genotype among Estonians [34].
Recent studies have shown that subjects with intolerance to lactose tend to reduce their consumption of milk, which is predictable as far as they suffer from symptoms after milk consumption [31,35-38]. In our previous study [7] subjects showed no differences between genotypes in the frequency of GI complaints during life. We found, however, that the consumption of milk is extremely low among the Northern Russian population compared with other Northern populations. Does milk consumption influence the appearance of GI symptoms in a population with a high frequency of the lactase non-persistent genotype but with very low consumption of milk on the whole?

In the present study we sought to test two hypotheses: 1) subjects with lactase non-persistent genotype $(-13910 \mathrm{C} / \mathrm{C})$ possibly have more gastrointestinal symptoms associated with milk 2) subjects with lactase nonpersistence avoid using milk.

\section{Methods}

\section{Study population}

Students aged 17 to 26 years were randomly selected for this investigation from different departments in the Northern State Medical University (NSMU) during the period from 2006 to 2008. Blood samples $(\mathrm{n}=241)$ or buccal samples $(\mathrm{n}=277)$ were taken from 518 subjects in total for the genotyping of the lactase activity-defining $-13910 \mathrm{C} / \mathrm{T}$ variant.

The first group were recruited during the period 20062007 and blood samples were drawn for the genotyping. The second group were recruited during the period 2007-2008 and buccal samples were taken for the same purpose. The mean age for whole group was $19.8 \pm$ 1.72. Women represented $78.2 \%$ of all participants. Both groups of students were similar with respect to distributions of age and gender.

For randomization we used the official list of students of the NSMU. Since there are 16 faculties in the University and each has 10 to 12 groups of students we took for our study every third group from every fourth faculty.

The study was approved by the Ethics Committee of the NSMU (No 08/06 from 29.11.2006). All subjects gave their informed consent to participate.

\section{Analyses of genotype}

Blood samples were genotyped at the Department of Medical Genetics, University of Helsinki. Buccal samples were genotyped at the Forensic Laboratory in the University of Tampere.

Genotyping of blood samples was performed as previously described [11]. DNA was amplified by polymerase chain reaction (PCR). We used Taq polymerase (Dynazyme, Finnzymes, Espoo, Finland) with the 
conditions described elsewhere. The forward primer used was 5'-CCTCGTTAATACCCACTGACCTA-3' and the reverse primer was 5'-GTCACTTTGATATGATGAGAGCA-3', which cover about 400 bp regions on both sides of the C/T-13910 variant. The PCR product was verified by $1.5 \%$ agarose gel electrophoresis (with ethidium bromide). The PCR products were purified using Shrimp Alkaline Phosphatase (USB) and Exonuclease I (New England Biolabs) at $37^{\circ} \mathrm{C}$ for $60 \mathrm{~min}$ and at $80^{\circ} \mathrm{C}$ for $15 \mathrm{~min}$.

In sequencing, a BigDye 3.1 terminator (Applied Biosystems) was used according to the manufacturer's instructions. Sequencing conditions were as follows: at $96^{\circ} \mathrm{C}$ for $1 \mathrm{~min}$, then 25 cycles at $96^{\circ} \mathrm{C}$ for $10 \mathrm{~s}$, at $55^{\circ} \mathrm{C}$ for $5 \mathrm{~s}$ and at $60^{\circ} \mathrm{C}$ for $4 \mathrm{~min}$. The sequencing reaction followed purification on Millipore Multiscreen plates (Millipore, USA) with Sephadex G-50 Superfine sepharose (Amersham Biosciences, Sweden), electrophoresis by ABI 3730 DNA Analyzer (Applied Biosystems) and base calling by Sequencing Analysis 5.2 software (Applied Biosystems). The sequence obtained was analyzed using Sequencher 4.6. software (Gene Codes, USA).

The polymorphism of lactase persistence/non-persistence SNP rs4988235 from buccal samples was determined by TaqMan Human Custom Genotyping Assay from Applied Biosystems. The assay was performed according to the instructions provided with the assay with an ABI Prism 7900 HT sequence detection system (AppliedBiosystems, California, USA).

\section{Questionnaire}

All subjects gave written informed consent and filled in a questionnaire covering their personal data, selfreported condition of health, GI symptoms and milk consumption habits. We used the questionnaire with permission from Sahi [10].

Gastrointestinal symptoms were estimated by the question "Have you ever experienced the following symptoms and in what frequency?" The question was not intended to clarify the connection between milk consumption and symptoms. The various answers were "Every day", "At least once per week", "Every second week", "Sometimes". If the participant had never had the symptom the item was left blank. We classified the answer "Sometimes" together with no symptoms into one group and marked it "Without GI symptoms". The second group included the remaining variables and was taken for analyses of differences between genotypes.

The influence of food on the appearance of GI disorders was estimated by the question "Do you have any GI disorders if you consume the following types of food?" where six types of food being included. Subjects were asked to put "Yes" or "No" opposite every type of food.
In the last part of the questionnaire subjects were asked to define their everyday milk product consumption from 0 to more than 5 glasses per day. The choices were "Not at all", "1-2 glasses", "3-5 glasses" and "More than 5 glasses" of milk/sour milk per day. There was also an option to declare consumption less than 1-2 glasses per day for those who consumed milk very rarely. For the analysis we classified all answers into two groups: less than daily milk consumption or none and daily milk consumption.

Comparison was made between the lactase non-persistent group $(-13910 \mathrm{C} / \mathrm{C})$ and the lactase persistent group $(-13910 \mathrm{C} / \mathrm{T}$ and $-13910 \mathrm{~T} / \mathrm{T})$ for all the above-mentioned questions.

\section{Statistical analysis}

The difference between genotype groups in milk consumption and others were tested by $\chi 2$ test. Odds ratios (OR) with 95\% confidence interval (CI) for $-13910 \mathrm{C} / \mathrm{C}$ genotype in the logistic regression analysis were calculated for gastrointestinal symptoms in total and symptoms after several types of food, and for volume of milk/ sour milk consumption. Statistical analyses were performed with SPSS version 15.0 (SPSS Inc. Chicago, IL, USA).

\section{Results}

The prevalence of the $-13910 \mathrm{C} / \mathrm{C}$ genotype (lactase nonpersistence, LNP) among 518 young students from North-West Russia was found to be $35 \%$ ( $\mathrm{n}=180$ ) while the $-13910 \mathrm{C} / \mathrm{T}$ genotype was found in $46 \%$ and $-13910 \mathrm{~T} / \mathrm{T}$ in $19 \%$ of participants.

About sixty percent of all subjects reported GI symptoms (Table 1). The most frequent symptom was stomach-ache. However, no statistically significant

Table 1 The frequency of gastrointestinal symptoms (GI) among young people with lactase-persistent/nonpersistent genotype (Question "Have you ever experienced the following symptoms?")

\begin{tabular}{|c|c|c|c|c|c|}
\hline \multirow[b]{2}{*}{ Gl symptoms } & \multicolumn{2}{|c|}{$\begin{array}{l}\text { Lactase non- } \\
\text { persistence } \\
\text { C/C-13910 } \\
(\mathrm{n}=180)\end{array}$} & \multicolumn{2}{|c|}{$\begin{array}{c}\text { Lactase } \\
\text { persistence } \\
\text { C/T and T/T- } \\
13910 \\
(n=338)\end{array}$} & \multirow[b]{2}{*}{$\mathrm{p}$} \\
\hline & $n$ & $\%$ & $n$ & $\%$ & \\
\hline Stomach-ache & 93 & 51.7 & 176 & 51.9 & 1.00 \\
\hline Regurgitation & 23 & 12.8 & 42 & 12.4 & 0.89 \\
\hline Flatulence & 17 & 9.4 & 38 & 11.2 & 0.65 \\
\hline Heartburn & 14 & 7.8 & 23 & 6.8 & 0.72 \\
\hline Nausea & 13 & 7.2 & 25 & 7.4 & 1.00 \\
\hline Diarrhea & 3 & 1.7 & 12 & 3.5 & 0.28 \\
\hline Without Gl symptoms & 74 & 41.1 & 142 & 42.2 & 0.71 \\
\hline
\end{tabular}


differences were revealed in the frequency of gastrointestinal symptoms in total between the LP and LNP genotype groups. The study brought out no statistically significant differences in symptom appearance between male and female participants.

The majority of subjects consumed very small amounts of milk daily. Only about $40 \%$ of all participants used milk every day. Almost 50\% did not use milk at all and $13 \%$ reported consumption of milk more seldom than daily (Table 2). Among carriers of the LNP genotype there were 10 percentage units fewer milkconsumers in comparison with the LP group (32.2 and $42.0 \%)$. The differences were statistically significant $(\mathrm{p}=$ 0.03 ). Sour milk consumption did not show significant differences in symptoms between LP and LNP subjects.

Milk consumption was associated with GI disorders in $13.3 \%$ of subjects with the LNP genotype and in $7.1 \%$ of subjects with the LP genotype (Table 3). Complaints of GI disorders caused by milk consumption were different between the genotypes $(\mathrm{p}=0.02)$.

Among all types of food analyzed only milk resulted in statistically significant differences in symptoms between LP and LNP subjects (OR $=1.95, \mathrm{CI} 1.03-3.69)$ (Table 4). In regression analysis there was no connection between consuming food and the appearance of symptoms except in milk consumption.

\section{Discussion}

Young Northern Russians consume very small amounts of milk daily. However, among LNP genotype carriers there are even less milk-consumers than among LP subjects. Our findings demonstrate that milk is the only type of food having an influence upon the appearance of GI disorders differently by genotype. We may conclude that subjects with lactase non-persistence $(-13910 \mathrm{C} / \mathrm{C})$ have more symptoms from milk. Subjects with lactase non-persistent genotype avoid using milk.

Sour milk consumption brought out no differences between the genotypes. This is in accord with the previous proved finding that sour milk is better tolerated than milk by persons with lactose intolerance $[21,39]$. Sour milk contains less lactose as a result of bacterial fermentation.

Table 2 Milk consumption by genotype

\begin{tabular}{lcccc}
\hline $\begin{array}{l}\text { Consumption } \\
\text { of milk }\end{array}$ & $\begin{array}{c}\text { Lactase non- } \\
\text { persistence } \\
\mathbf{- 1 3 9 1 0 C / C} \\
(\mathbf{n}=\mathbf{1 8 0})\end{array}$ & $\begin{array}{c}\text { Lactase persistence } \\
-\mathbf{1 3 9 1 0 C / T} \text { and } \\
-13910 T / T \\
(\mathbf{n}=\mathbf{3 3 8})\end{array}$ \\
\cline { 2 - 5 } & $\mathbf{n}$ & $\mathbf{\%}$ & $\mathbf{n}$ & $\%$ \\
\hline Less than daily or none & 122 & 67.8 & 196 & 58.0 \\
\hline Daily & 58 & 32.2 & 142 & 42.0 \\
\hline Total & 180 & 100 & 338 & 100 \\
\hline
\end{tabular}

Table 3 The frequency of GI disorders connected to different food stuffs (Question "Do you have any GI disorders if you consume the following types of food?")

\begin{tabular}{|c|c|c|c|c|c|}
\hline \multirow[t]{2}{*}{ Type of food } & \multicolumn{2}{|c|}{$\begin{array}{c}\text { Lactase non- } \\
\text { persistence } \\
-13910 \mathrm{C} / \mathrm{C} \\
(\mathrm{n}=180)\end{array}$} & \multicolumn{2}{|c|}{$\begin{array}{c}\text { Lactase persistence } \\
-13910 \mathrm{C} / \mathrm{T} \text { and } \\
-13910 \mathrm{~T} / \mathrm{T} \\
(\mathrm{n}=338)\end{array}$} & \multirow[t]{2}{*}{$p$} \\
\hline & $\bar{n}$ & $\%$ & $\mathrm{n}$ & $\%$ & \\
\hline Fatty & 56 & 31.1 & 120 & 35.5 & 0.33 \\
\hline Fried & 43 & 23.9 & 69 & 20.4 & 0.37 \\
\hline Milk & 24 & 13.3 & 24 & 7.1 & 0.02 \\
\hline Sour milk and kefir & 16 & 8.9 & 17 & 5.0 & 0.09 \\
\hline Vegetables & 10 & 5.6 & 14 & 4.1 & 0.51 \\
\hline Fruits & 7 & 3.9 & 19 & 5.6 & 0.53 \\
\hline Any other food & 28 & 15.6 & 52 & 15.4 & 1.00 \\
\hline Not any food & 88 & 47.6 & 174 & 51.6 & 0.74 \\
\hline
\end{tabular}

All students recruited for this study were considered healthy. However, only forty per cent of them did not report any GI symptoms and half of them reported stomach-ache, which was the most frequent symptom among all subjects without links to genotype. Possibly this finding requires further investigation of student health to clarify the causes of the frequent GI disorders among a healthy young population.

Table 4 Odds ratios (OR, $95 \% \mathrm{Cl}$ ) of the lactase nonpersistent genotype $(-13910 \mathrm{C} / \mathrm{C})$ in the logistic regression analysis for gastrointestinal symptoms, symptoms after some food and milk consumption.

\begin{tabular}{lc}
\hline Gl symptoms & $\begin{array}{c}\text { OR } \\
(95 \% \text { Cl) }\end{array}$ \\
\hline Diarrhea & $2.12(0.58-7.76)$ \\
\hline Flatulence & $1.17(0.62-2.21)$ \\
\hline Nausea & $1.04(0.50-2.14)$ \\
\hline Stomach pain & $1.00(0.68-1.46)$ \\
\hline Regurgitation & $0.98(0.53-1.76)$ \\
\hline Heartburn & $0.82(0.39-1.71)$ \\
\hline Symptoms after some food & \\
\hline Milk & $\mathbf{1 . 9 5}(1.03-\mathbf{3 . 6 9})$ \\
\hline Sour milk and kefir & $1.61(0.75-3.43)$ \\
\hline Fried & $1.61(0.97-2.67)$ \\
\hline Vegetables & $1.25(0.52-3.00)$ \\
\hline Any other food & $1.02(0.59-1.75)$ \\
\hline Fatty & $0.68(0.43-1.07)$ \\
\hline Fruits & $0.52(0.20-1.31)$ \\
\hline Milk product consumption & \\
\hline Milk & $\mathbf{1 . 5 1 ( 1 . 0 4 - \mathbf { 2 . 1 7 } )}$ \\
\hline Sour milk & $1.10(0.76-1.60)$ \\
\hline
\end{tabular}

Statistically significant differences are presented in bold face. 
Regarding other populations it was shown that only flatulence occurs significantly more frequently among LNP subjects $[39,40]$. Jussila and associates [41] showed that loose stool was a more frequent symptom in subjects with selective lactose malabsorption.

The northern Russians use very small amount of milk daily. However LNP subjects use less milk than people with LP genotype. Such a self-prescribed reduction is in agreement with a study in Finnish children with the $-13910 \mathrm{C} / \mathrm{C}$ genotype, who naturally diminished their usage of milk [31] and also with a study in children of other ethnicities [42]. It was also shown that other age groups also tend to reduce their milk consumption because of the appearance of symptoms after milk $[24,38]$.

It is possible to assume that the low rate of symptoms was partly related to the low milk intake in our study population. It is likely even if the prevalence of adult type hypolactasia in the study population is as much as $35 \%$ and low milk consumption is reported symptoms appear less probably than in other populations. Another explanation for the low rate of symptoms may be the age of lactase activity down-regulation. Since there are no studies estimating the age of decline of enzymatic activity in Russians there is a slight possibility that this group was too young to demonstrate differences in GI disorders.

Vast majority of our randomly selected students were from North-West Russia [7]. Based on the farming history, this area was determined in Soviet Union as milk production area. The region has still been considered as one of the country's milk and meat production areas. The gene-culture co-evolution between cattle milk genes and humans lactose tolerance has been verified for North Central Europe [43] and it seems to be also in north-western part of Russia.

Since milk is an important source of nutrients there are numerous studies aimed to demonstrate the advantages and disadvantages to milk restriction or elimination from the diet. The lack of milk in nutrition in the young population is strongly associated with decreased bone mineral density and leads to osteoporosis in older age [42]. Precise statistic data of prevalence of osteoporosis among the Russian population are lacking. However, it is obvious that osteoporosis as well as a higher risk of bone fractures connected with it is an actual problem for Russia [44]. Building peak bone mass during childhood and adolescent can be the best means of preventing osteoporosis in older age.

\section{Conclusions}

It is surely warranted to increase milk consumption among the Russian population by providing a federal program. The benefits from an increase in milk consumption are obvious. At the same time our study has shown that lactase non-persistent subjects have higher frequency of GI disorders even in population with very small amount of milk consumed. It may be predicted that in the case of increasing milk consumption symptoms may appear more frequently and may increase the need for medical consultation and care. It is therefore important either for people themselves or for health care staff to be alert to lactase persistence/ non-persistence.

\section{Acknowledgements}

Financial support of The Sigrid Jusélius Foundation is greatly acknowledged.

\section{Author details}

'Department of Family Medicine, Northern State Medical University, Arkhangelsk 163000, Russia and Medical School, Tampere University 33014, Finland. ${ }^{2}$ Department of Medical Genetics, University of Helsinki, Helsinki 00014, Finland. ${ }^{3}$ Medical School, University of Tampere and Tampere University Hospital 33014, Finland. ${ }^{4}$ School of Health Sciences, University of Tampere, Tampere 33014, Finland. ${ }^{5}$ Medical School, University of Tampere, 33014 and Center of General Practice, Hospital District of Pirkanmaa, Tampere 33521, Finland.

\section{Authors' contributions}

YK designed the research, collected the material, processed the data, and drafted the manuscript. ST made the genotyping of blood samples. ST made the genotyping of buccal samples and drafted the manuscript. IJ designed the research, supervised the research, and helped to draft the manuscript. PK supervised of analyses of genotypes (buccal samples), and help to draft the manuscript. Ml proposed the study idea, supervised, supported and designed the study, and drafted the manuscript. KM supervised, supported and designed the study, supervised data processing, and drafted the manuscript.

All authors read and approved the final manuscript.

\section{Competing interests}

The authors declare that they have no competing interests. This research received no specific grant from any funding agency in the public, commercial or not-profit sectors.

Received: 6 April 2011 Accepted: 13 November 2011

Published: 13 November 2011

\section{References}

1. Haug A, Høstmark AT, Harstad OM: Bovine milk in human nutrition - a review. Lipids in Health and Disease 2007, 6:25.

2. Valenkevich LN, Yachontova Ol: Milk and milk products in doctor's practical work St-Petersburg, Prosveshenie; 2005, (book in Russian).

3. Bannan PM, Levitt MD: Calcium, dairy products, and osteoporosis: Implications of lactose intolerance. Primary Care Update for OB/GYNS 1996, 3(4):146-151.

4. Miller GD, Jarvis JK, McBean LD: The importance of meeting calcium needs with foods. J Am Coll Nutr 2001, 20(2 Suppl):168S-185S.

5. Weaver CM: Role of dairy beverages in the diet. Physiol Behav 2010, 100(1):63-66.

6. Review of Russian Dairy Market. Russian food \& drink magazine. 2008, 6 [http://www.foodmarket.spb.ru/eng/archive.php? year $=2010 \&$ article $=653 \&$ section].

7. Khabarova Y, Torniainen S, Nurmi H, Järvelä I, Isokoski M, Mattila K: Prevalence of lactase persistent/non-persistent genotypes and milk consumption in a young population in north-west Russia. World J Gastroenterol 2009, 15(15):1849-1853.

8. The national program "School milk". [http://www.schoolmilk.ru].

9. Sahi T, Isokoski M, Jussila J, Launiala K, Pyorala K: Recessive inheritance of adult-type lactose malabsorption. Lancet 1973, 13:823-826. 
10. Sahi T: The inheritance of selective adult-type lactose malabsorption. Scand I Gastroenterol 1974, 9(Suppl 30):1-73.

11. Enattah NS, Sahi T, Savilahti E, Terwilliger JD, Peltonen L, Järvelä IE: Identification of a variant associated with adult-type hypolactasia. Nat Genet 2002, 30:233-237.

12. Enattah NS, Kuokkanen M, Forsblom C, Natah S, Oksanen A, Järvelä I, Peltonen L, Savilahti E: Correlation of intestinal disaccharidase activities with the $-13910 C / T$ variant and age. World I Gastroenterol 2007, 13(25):3508-3512.

13. Tishkoff SA, Reed FA, Ranciaro A, Voight BF, Babbitt CC, Silverman JS, Powell K, Mortensen HM, Hirbo JB, Osman M, Ibrahim M, Omar SA, Lema G, Nyambo TB, Ghori J, Bumpstead S, Pritchard JK, Wray GA, Deloukas P: Convergent adaptation of human lactase persistence in Africa and Europe. Nat Genet 2007, 39(1):31-40.

14. Imtiaz F, Savilahti E, Sarnesto A, Trabzuni D, Al-Kahtani K, Kagevi I, Rashed MS, Meyer BF, Järvelä I: The T/G 13915 variant upstream of the lactase gene (LCT) is the founder allele of lactase persistence in an urban Saudi population. J Med Genet 2007, 44(10):e89.

15. Ingram CJ, Elamin MF, Mulcare CA, Weale ME, Tarekegn A, Raga TO, Bekele E, Elamin FM, Thomas MG, Bradman N, Swallow DM: A novel polymorphism associated with lactose tolerance in Africa: multiple causes for lactase persistence? Hum Genet 2007, 120:779-788.

16. Torniainen S, Parker MI, Holmberg V, Lahtela E, Dandara C, Järvelä IE: Screening of variants for lactase persistence/non-persistence in populations from South Africa and Ghana. BMC Genet 2009, 5:10-31.

17. Järvelä IE: Molecular diagnosis of adult-type hypolactasia (lactase nonpersistence). Scand J Clin Lab Invest 2005, 65(7):535-539.

18. Büning C, Genschel J, Jurga J, Fiedler T, Voderholzer W, Fiedler EM, Worm M, Weltrich R, Lochs H, Schmidt H, Ockenga J: Introducing genetic testing for adult-type hypolactasia. Digestion 2005, 71(4):245-250

19. Hollox E: Genetics of lactase persistence - fresh lessons in the history of milk drinking. Eur J Hum Genet 2005, 13(3):267-269.

20. Villako K, Maaroos H: Clinical Picture of Hypolactasia and Lactose Intolerance. Scand J Gastroenterol 1994, 202(Suppl):26-35.

21. Gudmand-Hoyer E: The clinical significance of disaccharide maldigestion. Am J Clin Nutr 1994, 59(Suppl 3):735S-741S

22. Suarez FL, Savaiano DA, Levitt MD: A comparison of symptoms after the consumption of milk or lactose-hydrolyzed milk by people with selfreported severe lactose intolerance. N Engl J Med 1995, 333(1):1-4.

23. Casellas F, Varela E, Aparici A, Casaus M, Rodríguez P: Development, validation, and applicability of a symptoms questionnaire for lactose malabsorption screening. Dig Dis Sci 2009, 54:1059-1065.

24. Savaiano DA, Boushey CJ, McCabe GP: Lactose intolerance symptoms assessed by meta-analysis: a grain of truth that leads to exaggeration. J Nutr 2006, 136(4):1107-1113.

25. Launiala K: The mechanism of diarrhea in congenital disaccharide malabsorption. Acta Paediatr Scand 1968, 57(5):425-432.

26. Arola H, Tamm A: Metabolism of lactose in human body. Scand J Gastroenterol Suppl 1994, 202:21-25.

27. Swallow DM, Poulter M, Hollox EJ: Intolerance to lactose and other dietary sugars. Drug metabolism and disposition 2001, 29(4):513-516.

28. Borinskaia SA, Kal'ina NR, Sanina ED, Kozhekbaeva ZhM, Gupalo Elu, Garmash IV, Ogurtsov PP, Parshukova ON, Boǐko SG, Veselovskii EM, Vershubskaia GG, Kozlov Al, Rogaev El, lankovskii NK: Molecular diagnosis and frequencies of primary hypolactasia in population of Russia and neighboring country. Mol Biol (Mosk) 2006, 40(6):1031-1036, (In Russian, abstract in English).

29. Kozlov A: Lactase intolerance (primary hypolactasia) in different population groups of Eurasia. Doctoral thesis Moscow; 2004, (in Russian).

30. Sahi T: Genetics and epidemiology of adult-type hypolactasia. Scand J Gastroenterol 1994, 202(Suppl):7-20.

31. Rasinpera H: Adult-Type Hypolactasia: genotype-phenotype correlation. Academic Dissertation University of Helsinki, Helsinki; 2006 [https://oa.doria.fi/ bitstream/handle/10024/1389/adulttyp.pdf? sequence=1].

32. Anthoni SR, Rasinperä HA, Kotamies AJ, Komu HA, Pihlajamäki HK, Kolho KL, Järvelä IE: Molecularly defined adult-type hypolactasia among working age people with reference to milk consumption and gastrointestinal symptoms. World I Gastroenterol 2007, 13(8):1230-1235.

33. Almon $R$, Engfeldt $P$, Tysk $C$, Sjöström $M$, Nilsson TK: Prevalence and trends in adult-type hypolactasia in different age cohorts in Central Sweden diagnosed by genotyping for the adult-type hypolactasia-linked LCT -13910 C > T mutation. Scand J Gastroenterol 2007, 42(2):165-170.

34. Lember M, Tornainen S, Kull M, Kallikorm R, Saadla P, Rajasalu T, Komu H, Järvelä I: Lactase non-persistence and milk consumption in Estonia. World J Gastroenterol 2006, 12:7329-7331.

35. Carroccio A, Montalto G, Cavera G, Notarbatolo A: Lactose intolerance and self-reported milk intolerance: relationship with lactose maldigestion and nutrient intake. Lactase Deficiency Study Group. J Am Coll Nutr 1998, 17(6):631-636.

36. Obermayer-Pietsch BM, Bonelli CM, Walter DE, Kuhn RJ, FahrleitnerPammer A, Berghold A, Goessler W, Stepan V, Dobnig H, Leb G, Renner W: Genetic predisposition for adult lactose intolerance and relation to diet, bone density, and bone fractures. J Bone Miner Res 2004, 19(1):42-47.

37. Lovelace HY, Barr SI: Diagnosis, symptoms, and calcium intakes of individuals with self-reported lactose intolerance. J Am Coll Nutr 2005, 24(1):51-57.

38. Kull M, Kallikorm R, Lember M: Impact of molecularly defined hypolactasia, self-perceived milk intolerance and milk consumption on bone mineral density in a population sample in Northern Europe. Scand J Gastroenterol 2009, 44(4):415-21.

39. Anthoni S: Cow's milk related gastrointestinal symptoms in adults. Academic Dissertation University of Helsinki; 2009 [https://oa.doria.fi/ bitstream/handle/10024/45470/cowsmilk.pdf?sequence=3].

40. Tamm A: Management of lactose intolerance. Scand J Gastroenterol 1994, 202(Suppl):26-35.

41. Jussila J, Isokoski M, Launiala K: Prevalence of lactose malabsorption in Finnish rural population. Scand J Gastroenterol 1970, 5(1):49-56.

42. Matlik L, Savaiano D, McCabe G, VanLoan M, Blue CL, Boushey CJ: Perceived milk intolerance is related to bone mineral content in 10- to 13-year-old female adolescents. Pediatrics 2007, 120(3):e669-77.

43. Beja-Pereira A, Luikart G, England PR, Bradley DG, Jann OC, Bertorelle G, Chamberlain AT, Nunes TP, Metodiev S, Ferrand N, Erhardt G: Gene-culture coevolution between cattle milk protein genes and human lactase genes. Nat Genet 2003, 35(4):311-3.

44. Benevolenskaia LI: [lssues of osteoporosis in present-day medicine]. Vestn Ross Akad Med Nauk 2003, 7: 15-9, Russian.

\section{Pre-publication history}

The pre-publication history for this paper can be accessed here: http://www.biomedcentral.com/1471-230X/11/124/prepub

doi:10.1186/1471-230X-11-124

Cite this article as: Khabarova et al:: Lactase non-persistent genotype influences milk consumption and gastrointestinal symptoms in Northern Russians. BMC Gastroenterology 2011 11:124.

\section{Submit your next manuscript to BioMed Central and take full advantage of:}

- Convenient online submission

- Thorough peer review

- No space constraints or color figure charges

- Immediate publication on acceptance

- Inclusion in PubMed, CAS, Scopus and Google Scholar

- Research which is freely available for redistribution

Submit your manuscript at www.biomedcentral.com/submit
C Biomed Central 